\title{
INCREASED UROBILINOGEN EXCRETION AND ACUTE HEMOLYTIC ANEMIA IN PATIENTS TREATED WITH SULFAPYRIDINE ${ }^{1}$
}

\author{
By LOWELL A. ERF and COLIN M. Mac LEOD \\ (From the Hospital of The Rockefeller Institute for Medical Research, New York City)
}

(Received for publication December 8, 1939)

The occurrence of acute hemolytic anemia in patients receiving certain sulfonamide compounds (1) has been the subject of numerous reports. The mechanism responsible for the development of the anemia is unknown. However, it has been shown by Brownlee (2), Rimington (3), and Rimington and Hemmings (4) that many of the sulfonamide drugs derange the metabolism of pigments associated with blood formation and destruction. Rimington has emphasized the fact that many of these compounds are capable of being oxidized to hydroxylamine and suggests that this oxidation product may be responsible for the breakdown of red blood cells which occasionally follows the administration of the sulfonamide group of chemicals.

During the course of administration of sulfapyridine to patients with pneumonia, acute hemolytic anemia was observed and, consequently, a study of the incidence of hemolysis following administration of the drug was undertaken.

It has been shown by a number of investigators that the estimation of the total urinary and fecal excretion of urobilinogen may be. used in human beings as an index of hemolysis. By this technique increases in the rate of hemolysis may be observed which might escape detection if routine clinical procedures only are used. It should be emphasized, however, that the total urinary and fecal excretion of urobilinogen must be determined if an index of the rate of blood destruction is to be obtained. Estimation of urinary urobilinogen alone does not yield this information since the greater portion of urobilinogen is normally excreted in the feces. Elevation of urinary urobilinogen values represents only the increased amount of pigment diverted from the feces to the urine, such as may occur in the presence of hepatic insufficiency or during very rapid hemolysis.

\footnotetext{
1 Given at the Thirty-First Annual Meeting of the American Society for Clinical Investigation, Atlantic City, May 1, 1939.
}

The content of urobilinogen in the feces and urine varies considerably in normal patients. Watson has stated that occasionally a normal individual may excrete as much as $250 \mathrm{mgm}$. of urobilinogen per day in the stools. Values as high as this were not encountered in the study of 26 normal individuals made in this laboratory. Total stool collections were made for 3- or 9-day periods and the urobilinogen output was found to vary from $75 \mathrm{mgm}$. to $150 \mathrm{mgm}$. a day. The urobilinogen excretion in the urine varied from $0.0 \mathrm{mgm}$. to less than $2 \mathrm{mgm}$. a day. These figures are in close agreement with those of Watson.

The present study deals primarily with the total urinary and fecal excretion of urobilinogen by 26 patients with pneumonia, of whom 20 were treated with sulfapyridine. The remaining 6 patients did not receive this drug.

\section{METHODS}

Estimation of urobilinogen in stools and urine. The Watson-Terwen method (5) was used for the estimation of urinary and fecal urobilinogen. Stools and urine were collected over 3-day periods and kept in the icebox. Determination of the urobilinogen content was performed on the day following each 3-day period. Most of the patients were given milk of magnesia to ensure a daily defecation and occasionally tap water enemata were used. Diarrhea was not present in any instance.

Hematological studies. These studies were made on oxalated venous blood except in the case of stained films where capillary blood was used. Hemoglobin was estimated by the Sahli method. Red cell volumes were measured in Wintrobe tubes. The reticulocytes were counted in preparations stained supravitally with brilliant cresyl blue and counterstained with Wright's stain.

Liver function tests. Liver function studies were made in several patients by means of the bilirubin retention test of Harrop and Barron (6) and the sodium benzoate excretion test described by Quick (7).

Urinary studies. In addition to frequent routine urinalyses, in a number of instances determinations of kidney function were made by the urea clearance test of M $\phi$ ller, MacIntosh and Van Slyke (8).

Sulfapyridine determinations. The sulfapyridine levels in blood and urine were estimated by a modification of 
TABLE I

Excretion of urobilinogen in 26 patients with pmeumonia, 20 of whom received sulfapyridine

\begin{tabular}{|c|c|c|c|c|c|c|c|c|c|c|c|}
\hline \multirow{3}{*}{$\underset{\text { ber }}{\text { Case }}$} & \multirow{3}{*}{ Age } & \multirow{3}{*}{ Sex } & \multirow{3}{*}{ Etiological agent } & \multicolumn{4}{|c|}{ Sulfapyridine } & \multicolumn{3}{|c|}{ Urobilinogen } & \multirow{3}{*}{ Comment } \\
\hline & & & & \multirow{2}{*}{$\begin{array}{l}\text { Total } \\
\text { dos- } \\
\text { age }\end{array}$} & \multirow{2}{*}{$\begin{array}{l}\text { Dura- } \\
\text { tion } \\
\text { of } \\
\text { treat- } \\
\text { ment }\end{array}$} & \multicolumn{2}{|c|}{$\begin{array}{l}\text { Blood level } \\
\text { during } \\
\text { therapy }\end{array}$} & \multicolumn{2}{|c|}{$\begin{array}{l}\text { Highest } \\
\text { excretion } \\
\text { per day }\end{array}$} & \multirow{2}{*}{$\begin{array}{l}\text { Dura- } \\
\text { tion } \\
\text { of } \\
\text { in- } \\
\text { creased } \\
\text { excre- } \\
\text { tion }\end{array}$} & \\
\hline & & & & & & $\underset{\text { eat }}{\text { High- }}$ & $\begin{array}{c}\text { Aver- } \\
\text { age }\end{array}$ & Feces & Urine & & \\
\hline & & & & Erams & days & \multicolumn{2}{|c|}{ merm. per ceste } & mgm. & mgm. & doys & \\
\hline
\end{tabular}

GROUP I

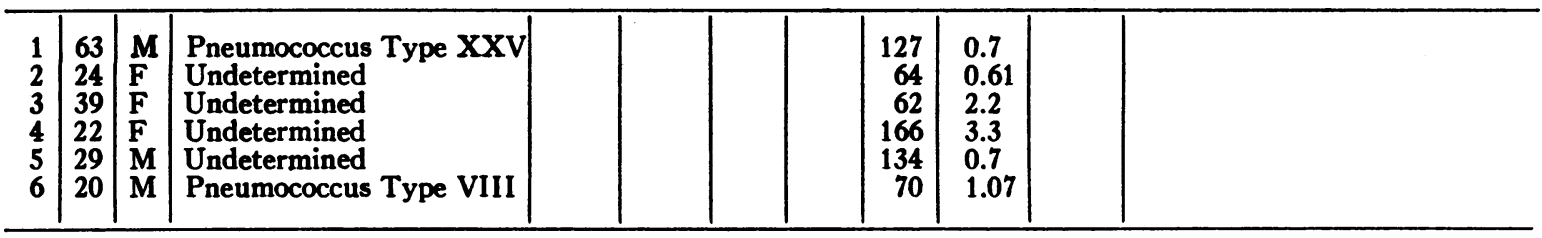

GROUP 11

\begin{tabular}{|c|c|c|c|c|c|c|c|c|c|c|}
\hline $\begin{array}{l}7 \\
8 \\
9\end{array}$ & $\begin{array}{l}44 \\
57 \\
58\end{array}$ & $\begin{array}{l}\mathbf{F} \\
\mathbf{M} \\
\mathbf{M}\end{array}$ & $\begin{array}{l}\text { Pneumococcus Type I } \\
\text { B. friedländerii } \\
\text { H. influenzae }\end{array}$ & $\begin{array}{l}17.0 \\
27.0 \\
18.0\end{array}$ & $\begin{array}{l}3 \\
7 \\
4\end{array}$ & $\begin{array}{r}11.1 \\
10.4 \\
2.2\end{array}$ & $\begin{array}{l}9.3 \\
6.7 \\
1.7\end{array}$ & $\begin{array}{r}80 \\
206 \\
208\end{array}$ & $\begin{array}{l}1.3 \\
1.6 \\
3.6\end{array}$ & $\begin{array}{l}\text { Coarctation of aorta } \\
\text { Bronchiectasis } \\
\text { Diabetes mellitus; empyema } H \text {. }\end{array}$ \\
\hline $\begin{array}{l}10 \\
11 \\
12\end{array}$ & $\begin{array}{r}5 \\
57 \\
66\end{array}$ & $\begin{array}{l}\mathbf{M} \\
\mathbf{M} \\
\mathbf{F}\end{array}$ & $\begin{array}{l}\text { Pneumococcus Type I } \\
\text { Pneumococcus Type III } \\
\text { Pneumococcus Type III }\end{array}$ & $\begin{array}{r}11.5 \\
22.0 \\
4.5\end{array}$ & $\begin{array}{l}5 \\
6 \\
2\end{array}$ & 7.1 & 6.7 & $\begin{array}{r}85 \\
174 \\
70\end{array}$ & $\begin{array}{l}0.75 \\
1.1 \\
0.6\end{array}$ & $\begin{array}{l}\text { Pulmonary tuberculosis } \\
\text { Auricular fibrillation; acute }\end{array}$ \\
\hline $\begin{array}{l}13 \\
14 \\
15 \\
16 \\
17\end{array}$ & $\begin{array}{l}75 \\
52 \\
72 \\
73 \\
65 \\
15\end{array}$ & $\begin{array}{l}\mathbf{M} \\
\mathbf{F} \\
\mathbf{F} \\
\mathbf{M}\end{array}$ & $\begin{array}{l}\text { Pneumococcus Type III } \\
\text { Pneumococcus Type IV } \\
\text { Pneumococcus Type VII } \\
\text { Pneumococcus Type VI } \\
\text { Pneumococcus Type III } \\
\text { Pneumococcus Type VII }\end{array}$ & $\begin{array}{r}13.0 \\
22.5 \\
10.0 \\
8.0 \\
14.0 \\
18.5\end{array}$ & $\begin{array}{l}4 \\
5 \\
3 \\
4 \\
4 \\
4\end{array}$ & $\begin{array}{l}8.2 \\
4.9 \\
4.3 \\
4.2 \\
4.6 \\
3.1\end{array}$ & $\begin{array}{l}6.5 \\
3.4 \\
4.3 \\
4.1 \\
3.1 \\
2.7\end{array}$ & $\begin{array}{r}157 \\
94 \\
83 \\
120 \\
127 \\
56\end{array}$ & $\begin{array}{l}1.4 \\
2.4 \\
1.1 \\
1.0 \\
1.3 \\
1.1\end{array}$ & $\begin{array}{l}\text { Received Type III rabbit serum } \\
\text { Chronic alcoholism } \\
\text { Received Type VI rabbit serum } \\
\text { Received Type III rabbit serum }\end{array}$ \\
\hline
\end{tabular}

GROUP III

\begin{tabular}{|c|c|c|c|c|c|c|c|c|c|c|c|}
\hline 19 & 52 & $\mathbf{M}$ & Pneumococcus Type III & 78.0 & 10 & 19.6 & 11.0 & 891 & 4.0 & 14 & $\begin{array}{l}\text { Acute hemolytic anemia, re- } \\
\text { ceived Type III rabbit serum; } \\
\text { alcoholism }\end{array}$ \\
\hline $\begin{array}{l}20 \\
21 \\
22 \\
23\end{array}$ & $\begin{array}{l}36 \\
59 \\
32 \\
41\end{array}$ & $\begin{array}{l}\mathbf{M} \\
\mathbf{F} \\
\mathbf{M}\end{array}$ & $\begin{array}{l}\text { Pneumococcus Type II } \\
\text { Pneumococcus Type VI } \\
\text { Undetermined } \\
\text { Non-hemolytic strepto- } \\
\text { coccus }\end{array}$ & $\begin{array}{l}81.0 \\
18.0 \\
19.5 \\
12.0 *\end{array}$ & $\begin{array}{r}11 \\
4 \\
4 \\
7\end{array}$ & $\begin{array}{l}7.7 \\
4.5 \\
6.7\end{array}$ & $\begin{array}{l}5.8 \\
3.0 \\
4.9\end{array}$ & $\begin{array}{l}561 \\
272 \\
585 \\
385\end{array}$ & $\begin{array}{c}0.99 \\
0.42 \\
11.5 \\
6.2\end{array}$ & $\begin{array}{r}10 \\
3 \\
20 \\
16\end{array}$ & $\begin{array}{l}\text { Acute hemolytic anemia } \\
\text { Empyema, died } 2 \text { months later } \\
\text { of brain abscesses }\end{array}$ \\
\hline $\begin{array}{l}24 \\
25 \\
26\end{array}$ & $\begin{array}{l}52 \\
18 \\
26\end{array}$ & $\begin{array}{l}\mathbf{F} \\
\mathbf{M}\end{array}$ & $\begin{array}{l}\text { Pneumococcus Type IX } \\
\text { Pneumococcus Type I } \\
\text { Pneumococcus Type III }\end{array}$ & $\begin{array}{l}24.0 \\
20.0 \\
25.0\end{array}$ & $\begin{array}{l}8 \\
5 \\
4\end{array}$ & $\begin{array}{r}3.9 \\
7.3 \\
12.6\end{array}$ & $\begin{array}{l}3.7 \\
4.6 \\
9.5\end{array}$ & $\begin{array}{l}452 \\
418 \\
400\end{array}$ & $\begin{array}{l}1.6 \\
2.7 \\
0.5\end{array}$ & $\begin{array}{l}7 \\
6 \\
4\end{array}$ & $\begin{array}{l}\text { Acute glossitis } \\
\text { Received Type III rabbit serum } \\
\text { Acute azotemia; acute hemo- } \\
\text { lytic anemia. }\end{array}$ \\
\hline
\end{tabular}

* Received 10.0 grams of sulfanilamide in addition.

Group I = Patients who did not receive sulfapyridine.

Group II = Patients receiving sulfapyridine in whom excretion of urobilinogen was not increased.

Group III = Patients receiving sulfapyridine in whom excretion of urobilinogen was increased.

the method used by Marshall and Litchfield (9) for the determination of sulfanilamide.

The patients on whom the studies were made were admitted to the hospital with a diagnosis of pneumonia. The diagnosis was confirmed in each case by physical and roentgenological examination, combined with careful studies of the sputum, blood, and exudates in order to determine the nature of the etiological agent.

Of the 26 patients, 18 suffered from pneumococcal pneumonia, and in 3 the disease was due respectively to $B$. friedländerii, a non-hemolytic streptococcus, and Hemophilus influenzae. 

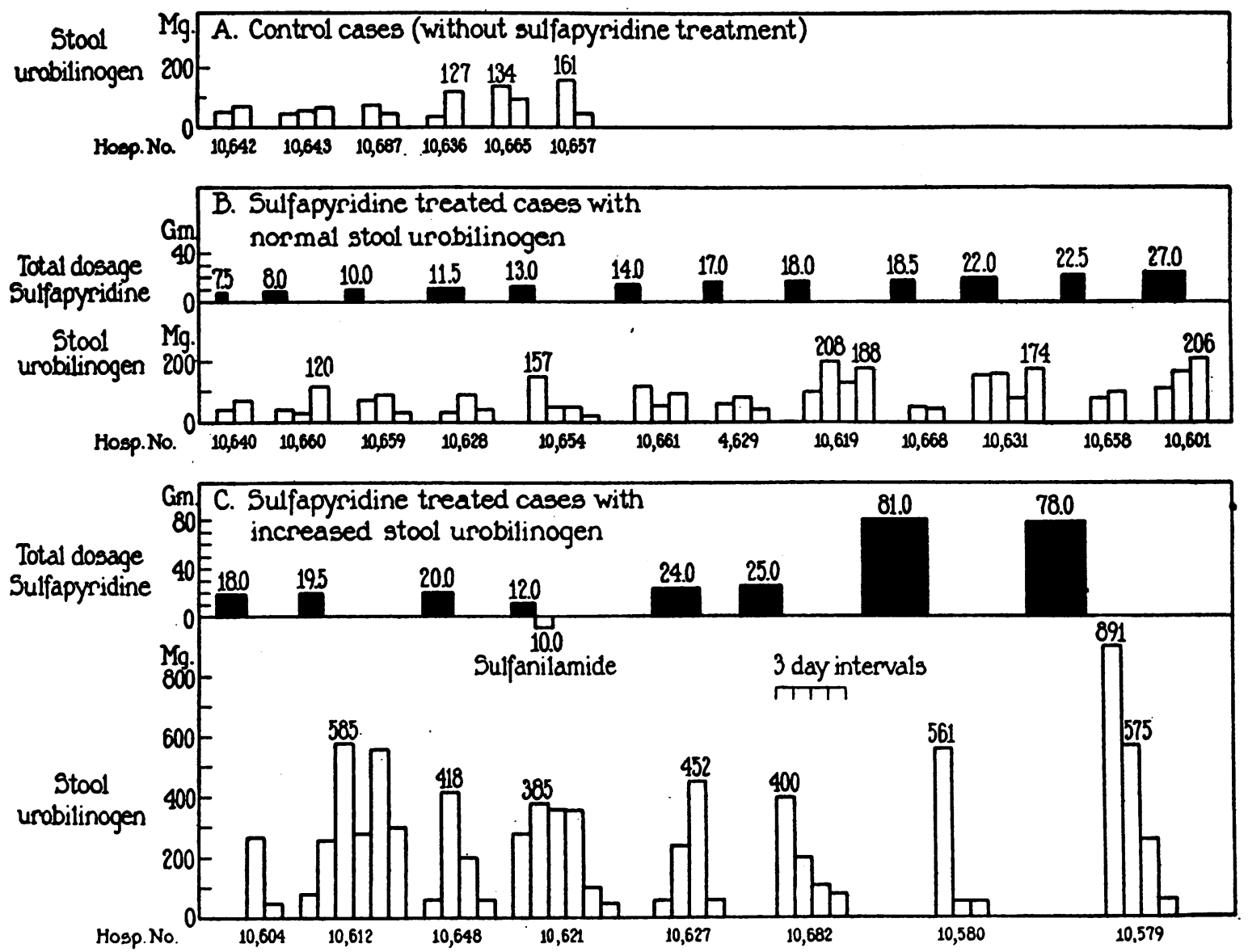

Fig. 1. Excretion of Urobilinogen in 26 Patients with Pneumonia, 20 of Whom Received SULFAPYRIDINE

In 5 patients the etiological agent was not ascertained. Bacteriological examination did not reveal any microorganism which was considered of etiological importance in this group and the serial passages of throat washings and pleural exudates in mice and ferrets did not produce disease. ${ }^{2}$

Selection of patients was not made except in the case of the first 2 individuals, both of whom developed acute hemolytic anemia almost simultaneously at the beginning of the study.

Sulfapyridine was administered by mouth only. The dose varied from case to case depending upon the blood level of the drug and the duration of acute signs and symptoms of pneumonia.

The patients may be divided conveniently into

2 These studies were performed by Dr. Frank L. Horsfall, Jr., of the International Health Division of the Rockefeller Foundation. three groups as indicated in Table I. The data are represented graphically in Figure 1.

Group I. Patients who did not receive sulfapyridine. None of the patients in Group I showed an excretion of urobilinogen in the stools above 166 mgm. per day. The highest urinary excretion was $3.3 \mathrm{mgm}$. Despite the presence of severe infection, in 3 patients the excretion of urobilinogen in the feces was $70 \mathrm{mgm}$. or less per day. In 4 of the 6 patients the etiology of the acute respiratory disease was not determined despite careful study. The other 2 had pneumococcal pneumonia.

Group II. Patients receiving sulfapyridine in whom excretion of urobilinogen was not increased. Ten of the 12 patients in Group II had pneumococcal pneumonia. In the remaining 2 the etiological agent was $B$. friedländerii and $H$. influenzae, respectively. The highest daily excretion 
of urobilinogen in the stools varied from $70 \mathrm{mgm}$. to $208 \mathrm{mgm}$. ; the highest urinary excretion varied between $0.6 \mathrm{mgm}$. and $3.6 \mathrm{mgm}$. The total dosage of sulfapyridine varied between 4.5 and 27.0 grams, the average blood levels of the free drug between $1.7 \mathrm{mgm}$. per cent and $9.3 \mathrm{mgm}$. per cent. Two patients received unconcentrated Type III antipneumococcal rabbit serum, and 1 concentrated Type VI antipneumococcal rabbit serum. In 6 patients other disorders complicated the pneumonic process.

Group III. Patients receiving sulfapyridine in whom excretion of urobilinogen was increased. Of the 8 patients included in this group, 6 suffered from pneumococcal pneumonia. In 1 patient the etiological agent was not determined and in 1 pneumonia and empyema were due to a strain of non-hemolytic streptococcus. In the latter patient death occurred 2 months after the present studies were completed and was due to multiple brain abscesses which developed at a time when convalescence from the primary disease process was well established. Non-hemolytic streptococci were recovered from the abscesses.

The highest daily excretion of urobilinogen in patients' feces in Group III varied from $272 \mathrm{mgm}$. to $891 \mathrm{mgm}$. ; these levels are well above those established as normal. The duration of increased urobilinogen output was from 3 to 20 days. In 4 patients the increased excretion lasted for 10,14 , 16 , and 20 days, respectively. The highest urinary urobilinogen excretion varied between 0.42 mgm. and $11.5 \mathrm{mgm}$. per day. The total dosage of sulfapyridine varied between 12.0 grams and 81.0 grams; however, the patient receiving the smallest dose was given 10.0 grams of sulfanilamide in addition. The average blood levels of free sulfapyridine were between 3.0 and $11.0 \mathrm{mgm}$. per cent. Two patients received unconcentrated Type III antipneumococcal rabbit serum as complementary treatment.

Three patients of this group developed acute hemolytic anemia. In 2 , the total dosage of sulfapyridine was high -78.0 and 81.0 grams, respectively. In the third patient the output of urine diminished sharply the day after sulfapyridine therapy was begun. Acute azotemia occurred with the development of oliguria, and this was associated with high blood levels of sulfapyridine which were maintained for several days despite

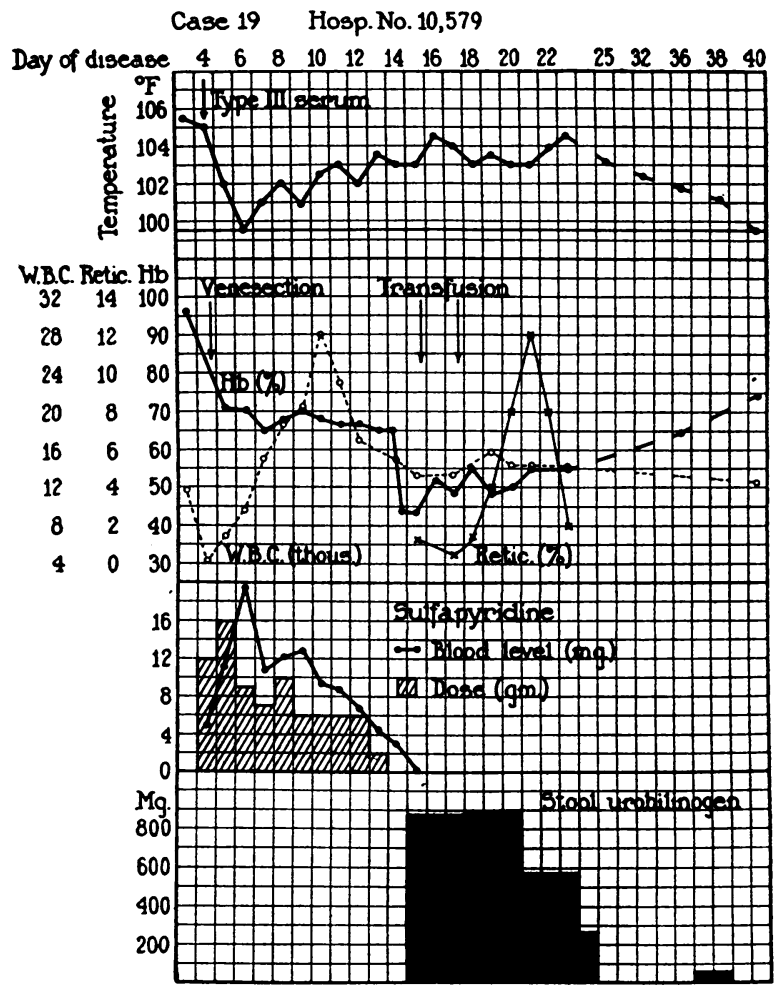

Fig. 2. Acute Hemolytic Anemia in Patient with Pneumonia Treated with Sulfapyridine

The temperature curve, blood changes, dosage and blood level of sulfapyridine, and excretion of urobilinogen in the feces are shown.

cessation of drug therapy. This patient developed a mild degree of hemorrhagic Bright's disease.

The case histories of the 3 patients who developed acute hemolytic anemia are briefly summarized.

\section{CASE REPORTS}

Case 19 (Figure 2). A .white male, aged 52, was admitted to the hospital 32 hours after the acute onset of lobar pneumonia. His past history was non-contributory except for the excessive use of alcohol. On admission consolidation of the left upper lobe was present. Large numbers of Type III pneumococci were present in the sputum. Temperature was $104.6^{\circ}$, pulse rate 96 , respiratory rate 26 . The leukocyte count was 11,900 , hemoglobin 96 per cent and the red blood cells numbered 5,060,000. Cultures of the blood showed no growth throughout the disease. Administration of unconcentrated Type III antipneumococcal rabbit serum was begun shortly after admission. Twenty-four hours later venesection was performed and $400 \mathrm{cc}$. of blood withdrawn because of impending pulmonary edema. The hemoglobin level dropped to 70 per cent following venesection. Although Type III agglutinins were present in the patient's serum in a titer 
Case 20 Hosp. No. 10,580

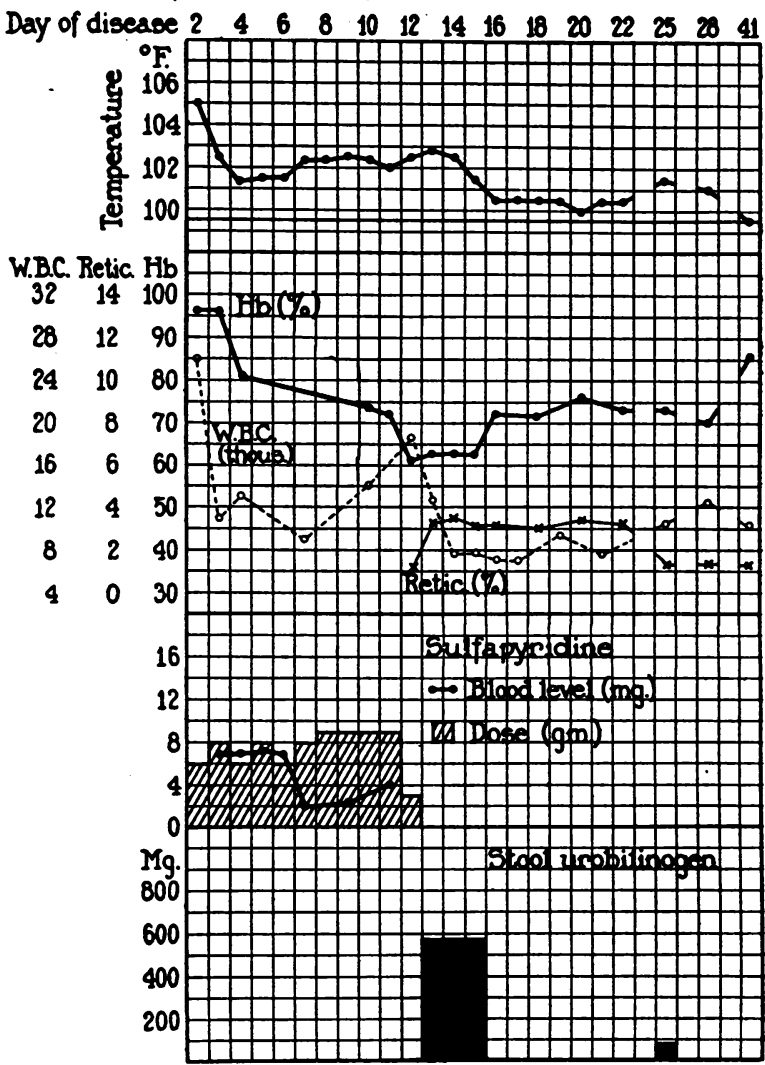

Fig. 3. Acute Hemolytic Anemia in Patient with Pneumonia Treated with Sulfapyridine

The temperature curve, blood changes, dosage and blood level of sulfapyridine, and excretion of urobilinogen in the feces are shown.

of $1: 256$, the skin test with the Type III polysaccharide remained negative. On the second hospital day the pneumonic process spread to involve the right lower lobe. The leukocyte count declined to 4,900. Sulfapyridine administration was begun, a total of 80 grams being given over the succeeding 10 days. The blood level of free sulfapyridine was $19.05 \mathrm{mgm}$. per cent 48 hours after drug therapy was begun. The dosage of sulfapyridine was reduced during the succeeding 8 days, and on the day on which it was discontinued the blood sulfapyridine level was $3.4 \mathrm{mgm}$. per cent. During the course of drug therapy no extension of the pneumonic process occurred within the right lower lobe, but involvement of the entire left lower lobe took place and necessitated continuing the administration of sulfapyridine. The temperature remained irregularly elevated. The leukocyte count rose following administration of the drug, 28,000 being the highest count noted. No nausea or vomiting occurred, cyanosis was minimal, and little evidence of drug toxicity was apparent.

Administration of sulfapyridine was discontinued after 10 days. The hemoglobin level had fallen from 70 per cent to 60 per cent during the course of treatment. The following day a marked increase in pallor was observed. Blood examination showed: hemoglobin 44 per cent; red blood cells 1,910,000; white blood cells 14,550. The patient was transfused with $500 \mathrm{cc}$. of whole blood. Transfusion was repeated 2 days later because of continued hemolysis.

For the 3-day period during which the hemolytic process was at its height and before transfusion, the daily urinary urobilinogen output averaged $4.0 \mathrm{mgm}$. while the stool urobilinogen per day for the same period averaged 891.0 mgm. Liver function was found to be within normal limits as measured by the sodium benzoate excretion and bilirubin retention tests. The urea clearance test reflected normal kidney function. There was a slight icteric tinge to the sclerae and the edge of the liver became palpable. In spite of the acute hemolytic process the reticulocyte count was below 2 per cent for the first 4 days after transfusion. A sharp rise to 12 per cent occurred during the succeeding 3 days, associated with a rise in hemoglobin to .55 per cent and of the hematocrit to 27 . The daily urinary urobilinogen output averaged $1.4 \mathrm{mgm}$; fecal urobilinogen $575 \mathrm{mgm}$. per day. Three days later the urobilinogen output in the urine had fallen to 0.37 mgm. per day and in the feces to $251.0 \mathrm{mgm}$. daily, indicating a marked decrease in blood destruction. Coincidentally, the hemoglobin level rose to 66 per cent, the hematocrit to 29 . On discharge 6 weeks later the patient's hemoglobin level was 90 per cent; hematocrit 35; urobilinogen in the urine measured $0.82 \mathrm{mgm}$. daily and in the feces $63 \mathrm{mgm}$. daily.

Case 20 (Figure 3). A white male, aged 36, was admitted to the hospital 36 hours after the typical acute onset of lobar pneumonia. Temperature on admission was $104^{\circ}$, pulse rate 120 , respiratory rate 38 . Moderate cyanosis was present. The red blood cells numbered 4,650,000; hemoglobin percentage was 97 , and the leukocyte count was 26,000 . Consolidation of the left upper lobe was present. The sputum contained large numbers of Type II pneumococci. Blood cultures were sterile throughout the illness.

Treatment with sulfapyridine was begun 2 hours after admission and was continued for 11 days, a total of 81.0 grams being given. The blood level of sulfapyridine was determined frequently and found to vary considerably. The highest blood level recorded was $7.7 \mathrm{mgm}$. per cent of the free drug on the third day of treatment, and during the last 4 days the blood level varied between 2 and 4 mgm. per cent. Persistence of fever and acute signs and symptoms were associated with the development of a lung abscess in the left upper lobe, which became obvious as the surrounding acute pneumonic process resolved.

On the sixth day of drug therapy a fine macular skin rash appeared. This was confined mainly to the trunk and upper extremities and did not cause itching. The rash gradually faded and was not noted after the eleventh day.

During the course of treatment a moderate decline in hemoglobin values occurred, but on the eleventh day the patient was noticeably paler. The hemoglobin had fallen 


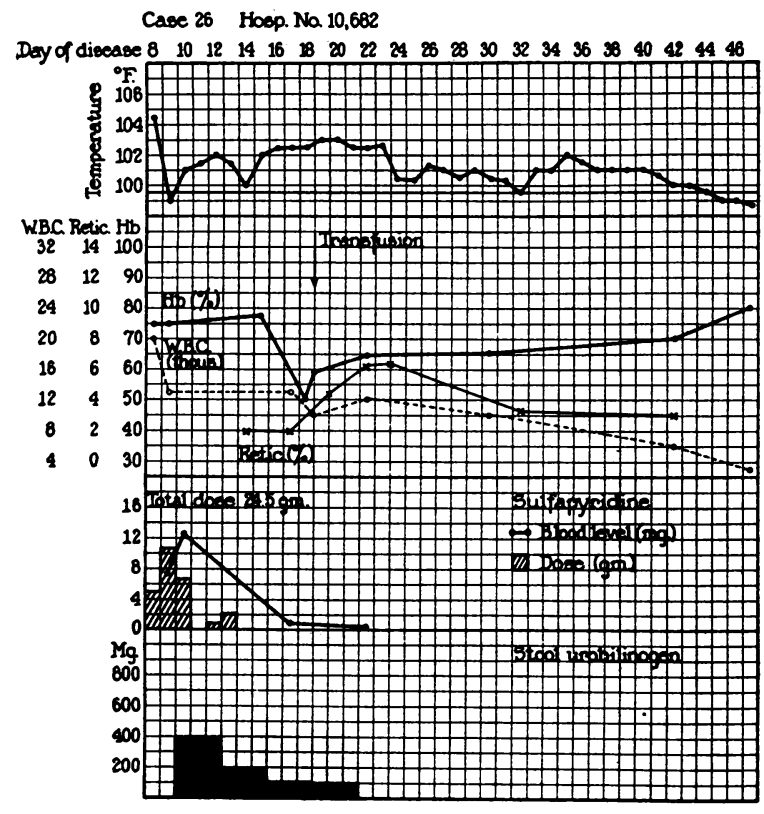

Fig. 4. Acute Hemolytic Anemia in Patient with Pneumonia Treated with Sulfapyridine

The temperature curve, blood changes, dosage and blood level of sulfapyridine, and excretion of urobilinogen in the feces are shown.

to 62 per cent and the red blood count to $3,040,000$; white blood cells numbered 12,800; reticulocytes 3.2 per cent; hematocrit 29 . At this time the average daily excretion of urobilinogen in the stool was $560 \mathrm{mgm}$. while that in the urine averaged $0.99 \mathrm{mgm}$. Transfusion was not considered necessary. The liver was not enlarged and there was no impairment of hepatic function, as measured by sodium benzoate excretion and bilirubin retention tests. Two weeks after the administration of the drug had been discontinued the hemoglobin level had risen to 74 per cent ; red blood cells numbered $3,440,000$; white blood cells 10,000 ; reticulocytes 1.4 per cent; hematocrit 31 . At this time the urobilinogen excretion in the urine was 0.40 $\mathrm{mgm}$. per day, and in the feces $74.5 \mathrm{mgm}$. Convalescence was much delayed due to the lung abscess which complicated the pneumonic process. Six weeks after admission the blood examination showed hemoglobin 86 per cent, red blood cells 4,320,000, white blood cells 10,300 and hematocrit 33.5.

Case 26 (Figure 4). A white female, aged 25, was admitted to the hospital on the eighth day following the onset of Type III pneumococcal pneumonia. Her past history was non-contributory. Consolidation of the right middle, right lower, and left upper pulmonary lobes was present. Temperature was $104.2^{\circ}$, pulse rate 132 , respiratory rate 40 . Blood cultures were sterile throughout the illness. Red blood cells numbered 3,790,000, hemoglobin level 74 per cent, leukocytes 21,450; urinalysis showed no abnormality; blood pressure was 112 systolic, 66 diastolic.
Twenty-five grams of sulfapyridine were given by mouth during the first 4 days following admission. Nausea and vomiting occurred and were fairly severe. The free sulfapyridine level in the blood was $12.6 \mathrm{mgm}$. per cent 36 hours after drug therapy was begun. This was associated with a marked diminution in the volume of urine. The patient's temperature and pulse rate fell to normal on the day following admission and agghutinins for pneumococcus Type III were demonstrable in her blood serum. The skin reaction to the Type III polysaccharide was positive at this time. Five days after discontinuing the administration of sulfapyridine, the blood level of the free drug was $1.0 \mathrm{mgm}$. per cent, and in the urine the level was $12.4 \mathrm{mgm}$. per cent, indicating delayed excretion. The output of urine on this day was only $300 \mathrm{cc}$. The blood urea nitrogen was $61.0 \mathrm{mgm}$. per cent. Two days later the blood urea nitrogen level had fallen to $33.6 \mathrm{mgm}$. per cent and kidney function was 62 per cent of normal, as measured by the urea clearance test.

On the eleventh hospital day, urea clearance test showed 55 per cent of normal function; 1.4 grams of protein were excreted in the urine in 24 hours, and large numbers of granular casts were present. Centrifuged specimens showed only 2 to 4 red cells per high power field. The blood pressure was $162 / 92$. Edema of the face and extremities was present.

During the 4 days on which sulfapyridine was given the urobilinogen excretion in the feces averaged $400 \mathrm{mgm}$. daily; in the urine $0.2 \mathrm{mgm}$. per day. The blood examination showed practically the same findings as on admission. During the 3 days immediately following the cessation of drug therapy, the urobilinogen excretion in the feces declined to an average of $196 \mathrm{mgm}$. daily; in the urine to $0.5 \mathrm{mgm}$. By the twelfth hospital day the red blood cell count had fallen to $2,000,000$, with a hemoglobin of 50 per cent; the fecal urobilinogen excretion was 132 mgm. daily. A transfusion of $500 \mathrm{cc}$. of whole uncitrated blood was given. Two days later the red blood cells numbered $3,350,000$, leukocytes 20,000 , and the hemoglobin 66 per cent. Urobilinogen excretion in the feces continued to fall to a level of $114 \mathrm{mgm}$. daily.

Diminution in urinary output persisted for 20 days and was followed by a period of diuresis. Four weeks after onset of the renal complication kidney function had risen to 90 per cent of normal, as measured by the urea clearance test, but the urine continued to show a trace of albumin and a few granular casts for another month. On discharge 4 months after admission, the urea clearance test showed renal function to be 96 per cent of normal, and urinalysis showed no abnormality. Blood pressure was $128 / 78$. The red blood cell count was $4,800,000$; hemoglobin 96 per cent.

Cases 19 and 20 received large doses of sulfapyridine during periods of 10 and 11 days, the total dosage being 78 and 81 grams, respectively. Administration of the drug was prolonged in both instances because of the continuation of the acute disease ; in Case 19 spread of the pneumonic con- 
solidation occurred, and in Case 20 the acute process persisted in association with the development of a lung abscess. The blood levels of sulfapyridine are of interest in both of these patients. In Case 19 the maximum reached was $19.05 \mathrm{mgm}$. of the free drug per $100 \mathrm{cc}$. of blood on the third day of treatment. During the last 5 days of treatment the level declined from $12.6 \mathrm{mgm}$. per cent to $3.4 \mathrm{mgm}$. per cent. In Case 20 the highest blood level was $7.7 \mathrm{mgm}$. per cent and for the last 5 days of treatment it varied between 4.0 and 2.0 mgm. per cent. In Case 19 no signs of drug toxicity appeared other than acute hemolytic anemia. - Despite the large dosage of sulfapyridine nausea did not occur, and there was no obvious increase in cyanosis. Case 20 suffered from severe nausea and vomiting during the whole course of drug therapy and between the sixth and eleventh days of treatment a fairly generalized macular skin rash was present.

Case 26 received much less sulfapyridine than either of the above patients-25 grams over a 4day period. However, abnormally high levels of the free drug occurred in the blood and the excretion was delayed in association with marked oliguria.

Case 19 showed the most severe anemia of the 3 and the highest daily excretion of urobilinogen in the stools. Likewise, the reticulocyte response was most marked in this case.

In all 3 patients who developed anemia the greatest depression of hemoglobin occurred about the twelfth day after the initial administration of sulfapyridine, regardless of dosage. The significance of this fact is not clear.

\section{DISCUSSION}

The widespread use of sulfapyridine in the treatment of pneumococcal pneumonia and other diseases has made a knowledge of its toxic effects important. The purpose of this communication is to present evidence for the occurrence of increased hemolysis associated with the administration of sulfapyridine. An abnormally increased excretion of urobilinogen was noted in 8 of the 20 patients who received the drug and 3 of this group of 8 developed a severe degree of hemolytic anemia.

A correlation between the increased excretion of urobilinogen and the dosage of sulfapyridine cannot be made. However, in 2 of the patients who developed anemia a relatively high concentration of the drug in the blood was maintained for several days; in 1 by large oral dosages of sulfapyridine and in the second because of slow excretion presumably due to poor renal function.

The pneumonic process itself is apparently not responsible for increased erythrocyte destruction. The 6 patients of Group I who did not receive sulfapyridine, and the 12 of Group II who were treated with the drug, excreted normal amounts of urobilinogen even though suffering from acute febrile disease. However, the 8 patients of Group III who received the drug, excreted amounts of urobilinogen well above the limits of normal. Two patients in whom urobilinogen excretion was increased during the administration of sulfapyridine later excreted normal amounts when drug therapy was discontinued, even though acute febrile disease persisted.

The reason for increased hemolysis incident to the administration of sulfonamide compounds is not known. It is possible that certain patients vary in their susceptibility either to the sulfonamide compound itself or to one of the derivatives formed within the body. It is likewise possible that certain patients may convert more of the sulfonamide compound into hemolytic products than others, or else fail to detoxify and eliminate these products rapidly enough to prevent increased hemolysis.

\section{SUMMARY}

The excretion of urobilinogen in feces and urine has been measured in 26 patients with pneumonia, 20 of whom received sulfapyridine.

In 18 patients the excretion of urobilinogen was within normal limits. Twelve patients were treated with sulfapyridine and 6 did not receive the drug.

Eight patients who received sulfapyridine excreted increased amounts of urobilinogen. Hemolytic anemia occurred in 3 of these.

\section{BIBLIOGRAPHY}

1. a. Wood, W. B., Jr., Anemia during sulfanilamide therapy. J. A. M. A., 1938, 111, 1916.

b. Antopol, W., Applebaum, I., and Goldman, L., Two cases of acute hemolytic anemia with autoagglutination following sulfanilamide therapy. J. A. M. A., 1939, 113, 488. 
c. Koletsky, S., Fatal hemolytic anemia following the administration of sulfanilamide. J. A. M. A., 1939, 113, 291.

d. Flippin, H. F., Lockwood, J. S., Pepper, D. S., and Schwartz, L., The treatment of pneumococcic pneumonia with sulfapyridine; progress report on observations in 100 cases. J. A. M. A., 1939, 112, 529.

e. Long, P. H., and Wood, W. B., Jr., Observations upon the experimental and clinical use of sulfapyridine. II. The treatment of pneumococcal pneumonia with sulfapyridine. Ann. Int. Med., 1939, 13, 487.

2. Brownlee, G., The rôle of the aromatic amino group in deranged pigment metabolism. Biochem J., 1939, 33, 697.

3. Rimington, C., Disturbances of pigment metabolism following administration of drugs of the sulphonamide series and simpler related substances. Proc. Roy. Soc. Med., 1939, 32, 351.

4. Rimington, C., and Hemmings, A. W., Porphyrinuric action of drugs related to sulphanilamide. Biochem. J., 1939, 33, 960.

5. Watson, C. J., Studies of urobilinogen; improved method for quantitative estimation of urobilinogen in urine and feces. Am. J. Clin. Path., 1936, 6, 458.

6. Harrop, G. A., and Barron, E. S. G., The excretion of intravenously injected bilirubin as a test of liver function. J. Clin. Invest., 1931, 9, 577.

7. Quick, A. J., The synthesis of hippuric acid: a new test of liver function. Am. J. M. Sc., 1933, 185, 630.

8. a. Mфller, E., McIntosh, J. F., and Van Slyke, D. D., Studies of urea excretion; relationship between urine volume and rate of urea excretion by normal adults. J. Clin. Invest., 1928, 6, 427.

b. McIntosh, J. F., M $\phi l$ ler, E., and Van Slyke, D. D., Studies of urea excretion; influence of body size on urea output. J. Clin. Invest., 1928, 6, 467.

9. Marshall, E. K., and Litchfield, J. T., Jr., Determination of sulfanilamide. Science, 1938, 88, 85. 